\title{
Origin and development of exocrine pancreatic insufficiency in experimental renal failure
}

\author{
M M Lerch, P Hoppe-Seyler, W Gerok
}

\begin{abstract}
Chronic renal failure affects the physiological function of many organ systems. One of them is the exocrine pancreas. Although varying degrees of pancreatic insufficiency are the dominating clinical characteristic of uraemic pancreatic disease, it remains unclear whether this disease should be regarded as a manifestation of chronic pancreatitis, arising from recurring attacks of acute pancreatitis, or represents a distinct entity. The exocrine pancreas was studied in a model of experimental renal failure. The pancreas was removed from each rat at selected time points over eight weeks after subtotal nephrectomy and from a standard rat model of pancreatitis for comparison. The data show that the in vitro secretory response is considerably changed in renal failure (increased during early acute and decreased during chronic renal failure). While the pancreatic content of digestive enzymes progressively declines, DNA and protein synthesis increase over time. Acinar cell deletion is increased and accompanied by an increased rate of mitosis. This increased cellular turnover is not associated with tissue oedema, pancreatic fibrosis, inflammatory changes, autophagocytosis or subcellular redistribution of lysosomal hydrolases, all of which are characteristic for pancreatitis. The ultrastructural changes of uraemic pancreatic disease bear no resemblance to the changes seen in pancreatitis. It is concluded that the morphological and biochemical changes in early uraemic pancreatic disease are quite distinct, correspond with toxic damage of the pancreas, and are dominated by functional impairment and an increased cellular turnover. (Gut 1994; 35: 401-407)
\end{abstract}

While chronic renal failure (CRF) is associated with a significant incidence of chronic pancreatic disease $^{1}$ the introduction of haemodialysis into clinical practice has done little to reduce the pancreatic abnormalities found in CRF patients. The occurrence of pathological necropsy findings in the pancreas from patients who died during the haemodialysis era is even higher than during the preceding years when dialysis was not available and life expectancy after the onset of CRF was much shorter. ${ }^{2}$ The most common clinical presentation of this phenomenon is exocrine pancreatic insufficiency, ${ }^{3}$ but recurring attacks of pancreatitis ${ }^{45}$ and an imaging appearance resembling chronic pancreatitis ${ }^{6}$ are not uncommon. From experimental animal studies that attempted to mimic the clinical situation of CRF, a variety of morphological and biochemical findings have been reported $^{78}$; some of them closely resemble while others distinctly differ from those characteristic of acute and chronic pancreatitis.

We have investigated the exocrine pancreas over the first eight weeks of experimentally induced renal failure in rats. Our data show that the secretory response to hormone stimulation is considerably impaired during CRF and that an accelerated cell death and regeneration characterise this model of uraemic pancreatic disease.

\section{Material and methods}

\section{INDUCED RENAL FAILURE}

Female Sprague-Dawley rats (Jovanowas, Kissleg, Germany and Charles River Lab, Boston, Ma) weighing 150-180 g are anaesthetised with pentobarbital $(60 \mathrm{mg} / \mathrm{kg}$, intraperitoneally). Under sterile conditions the abdomen was entered through a midline incision. Renal failure was induced by resection of the complete left kidney and the cranial and caudal third of the right kidney. ${ }^{9}$ Animals recovered from anaesthesia within three hours and were kept on standard laboratory chow with free access to water until the end of the experiment. Groups of five animals were killed at selected time intervals up to eight weeks after subtotal nephrectomy. Sham operated animals whose fatty tissue was removed from the pole caps of either kidney served as controls and were pair fed to exclude nutritional effects.

\section{SECRETAGOGUE INDUCED PANCREATITIS}

As a standard for the comparison of changes induced by experimental renal failure with those of pancreatitis, we studied a number of characteristic phenomena that seem to be common in all experimental models of pancreatitis. These are, in particular, the development of pancreatic oedema, the formation of intracellular autophagic vacuoles, and the redistribution of lysosomal hydrolases from their original lysosomal fraction into the zymogen granule enriched subcellular fraction. ${ }^{10}$ As a model of pancreatitis we used a mild, non-lethal, oedematous form, which is induced by supramaximal stimulation with the cholecystokinin analogue caerulein." In brief, animals were supplied with jugular venous catheters and infused with a saline solution containing caerulein $(5 \mu \mathrm{g} / \mathrm{kg} / \mathrm{h}$, Farmitalia, Freiburg, Germany) for four hours. This period of supramaximal caerulein stimulation was sufficient to induce massive pancreatic oedema, formation of autophagic vacuoles in acinar cells, and the redistribution of lysosomal cathepsin B. Longer 
periods of treatment did not increase the magnitude of these signs of secretagogue induced pancreatitis. The pancreas from pancreatitis animals were used in parallel with the renal failure group for all experiments outlined below.

\section{EXOCRINE SECRETION}

Acinar cell secretion was studied in a kinetic perfusion model for pancreatic lobules as previously described. ${ }^{12}$ In brief, the pancreas was rapidly removed and oxygenated Krebs-Ringer medium containing glucose $(12.9 \mathrm{mM})$, 3hydroxybutyrate (5 $\mathrm{mM})$, aminoacids, and electrolytes in equal molar concentrations to rat serum was injected into the connective tissue of the organ. Lobules were dissected with 27 gauge needles under stereoscopic vision and perfused with oxygenated buffer in a PVC chamber at a rate of $1 \mathrm{ml} / \mathrm{min}$. Perfusate was collected in 15 minute intervals for 120 minutes. Lobules were perfused with medium containing cholecystokinin (CCK, 1.4 ${ }^{-8}$; Kabi-Karolinska, Stockholm) to stimulate maximal pancreatic secretion from the 10th to the 15 th minute. The resulting enzyme activity released into the medium was calculated as enzyme secretion/minute and is given as $\mathrm{U} / \mathrm{min} / \mu \mathrm{g}$ DNA minus basal secretion from control lobules perfused without CCK stimulation in the same experiment.

\section{PROTEIN SYNTHESIS}

Pancreatic lobules from animals after subtotal nephrectomy and controls were perfused as described above. ${ }^{14} \mathrm{C}$ phenylalanine $(0.25 \mu \mathrm{Ci} /$ $\mathrm{ml}$, New England Nuclear, Boston, $\mathrm{Ma}$ ) was added to the perfusate for 10 minutes from the start of the perfusion. A chase medium containing cold phenylalanine $(4 \mu \mathrm{mol})$ was perfused for 90 minutes. Lobules were homogenised at selected times by ultrasound in homogenisation buffer and centrifuged ( $150 \mathrm{~g}$ for 15 minutes) to remove unbroken cells and debris. Aliquots were mixed with an equal volume of cold $20 \%$ trichloroacetic acid and after incubation on ice for 120 minutes to precipitate proteins, samples were recentrifuged $\left(4000 \mathrm{~g}, 30\right.$ minutes, $\left.4^{\circ} \mathrm{C}\right)$. The pellet was washed twice in 5\% trichloroacetic acid and ethanol/ether $(3 / 1, \mathrm{vol} / \mathrm{vol})$ and was finally dissolved in $\mathrm{NaOH}(0 \cdot 2 \mathrm{M})$. Radioactivity was measured using a Kontron MR 300 liquid scintillation counter after addition of $10 \mathrm{ml}$ PPO/POPOP Toluol scintillation fluid.
Results were calculated in dpm/ $\mu$ g DNA and are given in per cent of control lobules perfused in the same experiments.

\section{SUBCELLULAR FRACTIONATION}

Subcellular fractions of pancreatic tissue were generated as described and characterised previously. ${ }^{13}$ Portions of the pancreas were quickly removed, trimmed of fat, minced with scissors, and homogenised with two strokes of a Dounce B glass homogeniser in iced buffer containing 3[N-morpholino] propanesulphonic acid (MOPS) $(5 \mathrm{mM}), \mathrm{MgSO}_{4}(1 \mathrm{mM})$ and sucrose $(240 \mathrm{mM})$ at $\mathrm{pH} 6 \cdot 5$. Unbroken cells, nuclei, and debris were removed by low speed centrifugation (150 $g, 15$ minutes, $4^{\circ} \mathrm{C}$ ) and the supernatant was considered to contain $100 \%$ of enzyme content for later calculations. This supernatant was centrifuged $\left(1300 \mathrm{~g}, 15\right.$ minutes, $\left.4^{\circ} \mathrm{C}\right)$ and the resulting zymogen granule enriched pellet was resuspended in the above buffer. The resulting supernatant was centrifuged again $(12000 \mathrm{~g}, 12$ minutes, $4^{\circ} \mathrm{C}$ ) to obtain a lysosome and mitochondria enriched pellet and a supernatant that contained microsomes and soluble components. Cathepsin B activity in subcellular fractions was measured according to McDonald and Ellis. ${ }^{14}$ Remaining portions of the pancreas were used for the subsequent assays.

ASSAYS

To estimate oedema the pancreas was removed, trimmed of fat, and portions of the pancreas were blotted dry, weighed, desiccated (48 hours, $160^{\circ} \mathrm{C}$ ), and weighed again to permit calculation of pancreatic water content as a percentage of total pancreatic weight. Other portions of the pancreas were minced, homogenised for 30 seconds, (Brinkman Polytron, Westbury, NY) in buffer containing MOPS ( $5 \mathrm{mM}$ ), sucrose (250 $\mathrm{mM})$, and $\mathrm{MgSO}_{4}(1 \mathrm{mM})$ at $\mathrm{pH} 6 \cdot 5$. Aliquots of this homogenate were used to measure amylase activity, ${ }^{15}$ lipase activity, ${ }^{16}$ DNA content, ${ }^{17}$ and protein concentration. ${ }^{18}$ Serum measurements of amylase, creatinine, and blood urea nitrogen were performed in blood samples drawn from the right ventricle at death and according to standard protocols. The collagen content of pancreatic tissue was determined with a cytochemical micromethod as reported by Lopez-de Leon and Rojkind. ${ }^{19}$

All chemicals and reagents were of the highest

Biochemical parameters of rats from the sham operated group (controls), after secreatogogue induced pancreatitis (pancreatitis), and after subtotal nephrectomy on day one and after week one, three, and eight

\begin{tabular}{|c|c|c|c|c|c|c|}
\hline Days after subtotal & ontrols & Hours & 7 Days & I Days & 56 Days & Pancreatitis \\
\hline $\begin{array}{l}\text { BUN mg } / 100 \mathrm{ml} \\
\text { Creatinine } \mathrm{mg} / 100 \mathrm{ml} \\
\text { Serum amylase U/1 } \\
\text { Amylase content U/ } / \mu \mathrm{g} \text { DNA } \\
\text { Lipase content } \mathrm{U} / \mu \mathrm{g} \mathrm{DNA} \\
\text { DNA content } \mu \mathrm{g} / 100 \mathrm{mg} \text { pancreas } \\
\text { Protein content } \mu \mathrm{g} / 100 \mathrm{mg} \text { pancreas } \\
\text { Collagen content } \mu \mathrm{g} / \mathrm{mg} \text { protein } \\
\text { Cell death } \% \text { of area } \\
\text { Mitotic index }\end{array}$ & $\begin{array}{c}40 \cdot 1(1 \cdot 5) \\
0 \cdot 5(0 \cdot 1) \\
2262(129) \\
1186(136) \\
1540(123) \\
264(23) \\
7 \cdot 6(0 \cdot 8) \\
47(4) \\
0 \cdot 01 \\
0.93(0 \cdot 28)\end{array}$ & $\begin{array}{c}334(70)^{\star} \\
7 \cdot 2(1 \cdot 3)^{\star} \\
3260(571)^{\star} \\
1230(186) \\
1620(210) \\
253(28) \\
7 \cdot 8(1 \cdot 1) \\
53(2) \\
1 \cdot 1(0 \cdot 5)^{\star} \\
0 \cdot 89(0 \cdot 31)\end{array}$ & $\begin{array}{c}106(5)^{\star} \\
3 \cdot 1(1 \cdot 4)^{\star} \\
2339(206) \\
1030(133) \\
1320(160) \\
323(25)^{\star} \\
7 \cdot 7(0 \cdot 9) \\
49(5) \\
3 \cdot 4) 1 \cdot 3)^{\star} \\
2 \cdot 1(0 \cdot 8)^{\star}\end{array}$ & $\begin{array}{c}108(8)^{\star} \\
2 \cdot 4(0 \cdot 9)^{\star} \\
2680(176) \\
863(83)^{\star} \\
1140(85)^{\star} \\
338(31)^{\star} \\
7 \cdot 9(1 \cdot 8) \\
57(3) \\
4 \cdot 1(1 \cdot 3)^{\star} \\
5 \cdot 4(1 \cdot 7)^{\star}\end{array}$ & $\begin{array}{c}98(13)^{\star} \\
1 \cdot 8(0 \cdot 3)^{\star} \\
2581(163) \\
850(86)^{\star} \\
1090(120)^{\star} \\
320(15)^{\star} \\
7 \cdot 6(1 \cdot 3) \\
55(2) \\
3 \cdot 2(1 \cdot 8)^{\star} \\
2 \cdot 9(1 \cdot 3)^{\star}\end{array}$ & $\begin{array}{c}49(2) \\
0 \cdot 6(0 \cdot 1) \\
19753(568)^{\star} \\
1472(263) \\
1739(291) \\
254(25) \\
7 \cdot 6(0 \cdot 9) \\
60(7) \\
12 \cdot 3(3)^{\star} \\
0 \cdot 89(0 \cdot 16)\end{array}$ \\
\hline
\end{tabular}

Experiments and assays as described in the text. Data represent means (SEM) from four or more animals of each interval. ${ }^{\star} \mathrm{p}<0.05$ for the statistical comparison with the respective control group. BUN=blood urea nitrogen. 

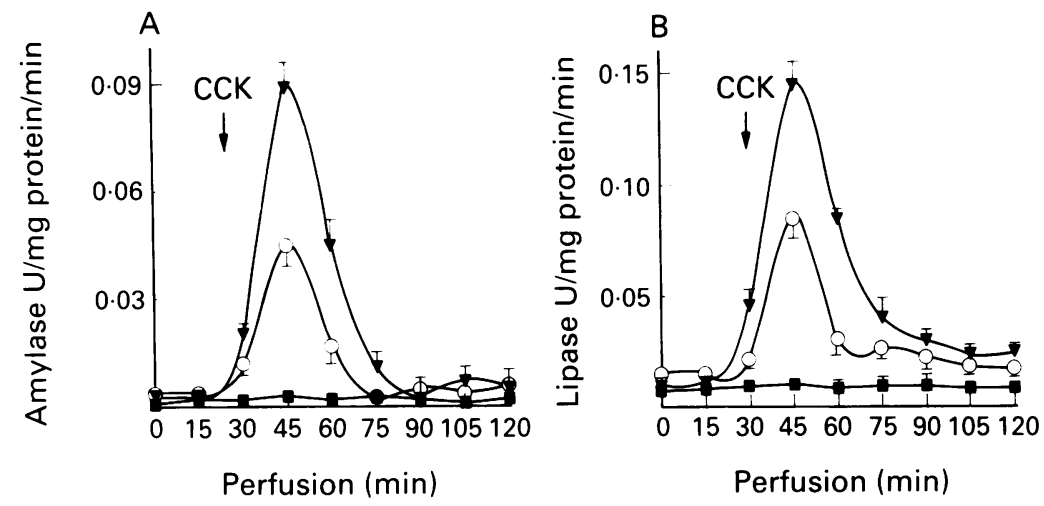

Figure 1: In vitro exocrine function of the pancreas. Stimulated amylase $(A)$ and lipase $(B)$ secretion from isolated pancreatic lobules 24 hours after subtotal nephrectomy and four hours after the start of a supramaximal secretagogue infusion. Lobules were prepared and perfused as described in the text. Cholecystokinin (CCK), at a dose calculated to deliver a maximal secretory response $\left(1 \cdot 4^{-8} M\right)$, was added to the perfusion buffer for five minutes after an initial equilibration period of 15 minutes. Data represent U/mg protein/min minus basal secretion from unstimulated control lobules mean (SEM) from four or more separate experiments. Symbols show animals after subtotal nephrectomy (closed triangles), sham operated controls (open circles), and animals with acute pancreatitis (closed squares).

purity available and purchased from either Sigma (St Louis, Mo), Polysciences (Warrington, Pa) or Merck (Rahway, NJ) unless shown otherwise.

\section{MORPHOLOGY}

Pieces from the head, body, and tail of the pancreas were fixed for histological examination in $10 \%$ neutral buffered formalin and $5 \mu \mathrm{m}$ paraffin wax sections from embedded tissue were stained with haematoxylin and eosin. To evaluate the extent of tissue fibrosis we stained paraffin wax sections with fast green FCF (Fluka, Switzerland) and sirius red F3BA (Gurr, $\mathrm{BDH}, \mathrm{UK}$ ).

Tissue for electron microscopy was cut to blocks of $1 \mathrm{~mm}$ in length and immediately fixed in $2 \%$ glutaraldehyde- $4 \%$ formaldehyde in phosphate buffer $(125 \mathrm{mM}$, pH 7.4) for 90 minutes, rinsed extensively in the same buffer, and post-

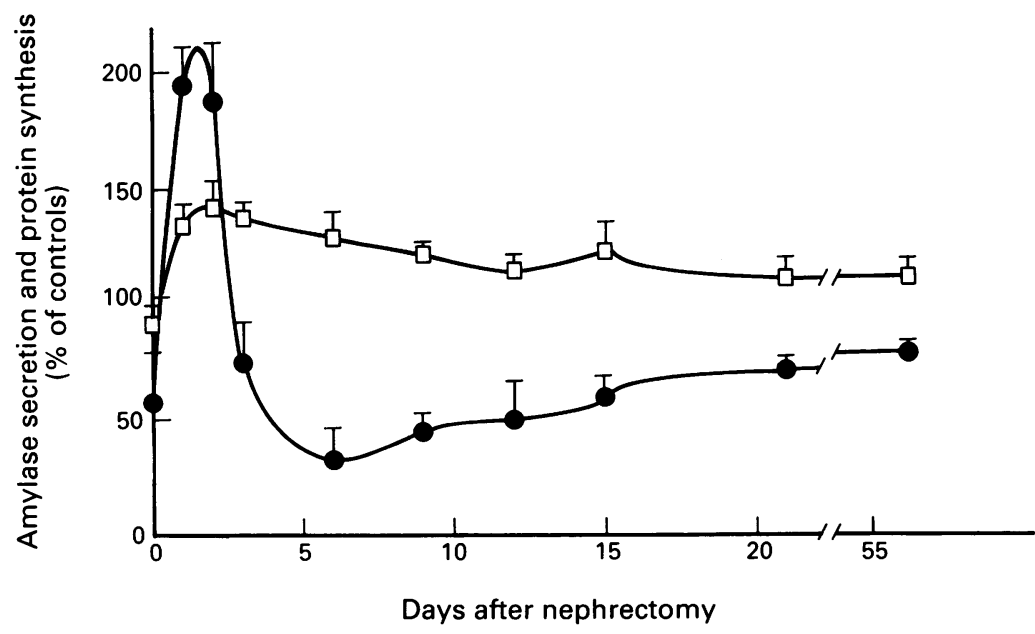

Figure 2: In vitro amylase secretion and protein synthesis over eight weeks after subtotal nephrectomy. Pancreatic lobules were prepared and perfused as described in the text. Amylase secretion was stimulated as shown in Figure 1 legend and protein synthesis, determined as acid precipitable protein after radioactive pulse labelling, was evaluated as described in the text. Data show either the cumulative amylase activity in the perfusion buffer secreted from the time of CCK stimulus until the end of stimulated response (closed circles) or radioactivity in $\mathrm{dpm} / \mu \mathrm{g}$ DNA (open squares) and are expressed in per cent of respective sham operated pairs. Data were generated from four or more animals at each interval and in each group. Error bars show SEM. fixed in $2 \% \mathrm{OsO}_{4}$. After dehydration in ethanol and embedding in Epon 812 or Araldite, semithin sections were stained with methylene blue for selection of areas for detailed study. Thin sections were cut on a LKB Ultratome, picked up on uncoated copper grids, double stained with uranyl acetate and lead citrate, and examined on a Philips 400 transmission electron microscope at 60 or $80 \mathrm{Kv}$. Sections were compared with specimens from control animals for light and electron microscopy.

\section{MITOTIC INDEX}

Five $\mu \mathrm{m}$ sections were stained with haematoxylin and eosin. Mitotic counts were carried out under oil immersion in square fields placed at random with a graticule on tissue sections. Differential counts of resting and dividing cells were performed until a total of 1.200 nuclei/ animal was counted. The results were expressed as accumulated frequency of mitotic figures as percentage of total mononuclear acinar cells scored. To avoid diurnal variations in mitotic counts, animals evaluated for mitotic index were all killed between 9 am and 12 noon.

\section{MORPHOMETRY}

Complete cross sections from the head, body, and tail of the pancreas were divided into three or four parts for light microscopic morphometric evaluation. After fixation and staining as above paraffin wax sections were photographed $(\times 40)$ covering all areas of each cross section from at least three different animals at every time interval. Photomicrographs were printed on heavy bonded paper. The prints were coded and the areas of paper occupied by necrotic acinar cells were marked, cut out, and weighed by a morphologist familiar with pancreatic disease but unaware of the experimental protocol used. The results were expressed as per cent of total acinar cell mass.

\section{ETHICAL APPROVAL}

All experimental protocols were approved by the Institutional Animal Care and Use committee and carried out according to the guiding principles of the American Physiological Society.

\section{DATA ANALYSIS}

The results reported in this study represent the mean values for at least four different animals at every time point. Error bars in the Figures show SEM values and the absence of these error bars point to SEM values too small to illustrate. To evaluate the significance of the changes seen, we used analysis of variance to compare the values from the animals killed at different intervals with their respective controls and pancreatitis animals. If analysis of variance pointed to significant differences, the means were evaluated by the method of Tukey ${ }^{20}$ as an additional test. The differences were considered significant if a $\mathrm{q}$ value was more than the critical value $(a \leqslant 0 \cdot 05)$. Asterisks in the Table show values significantly 


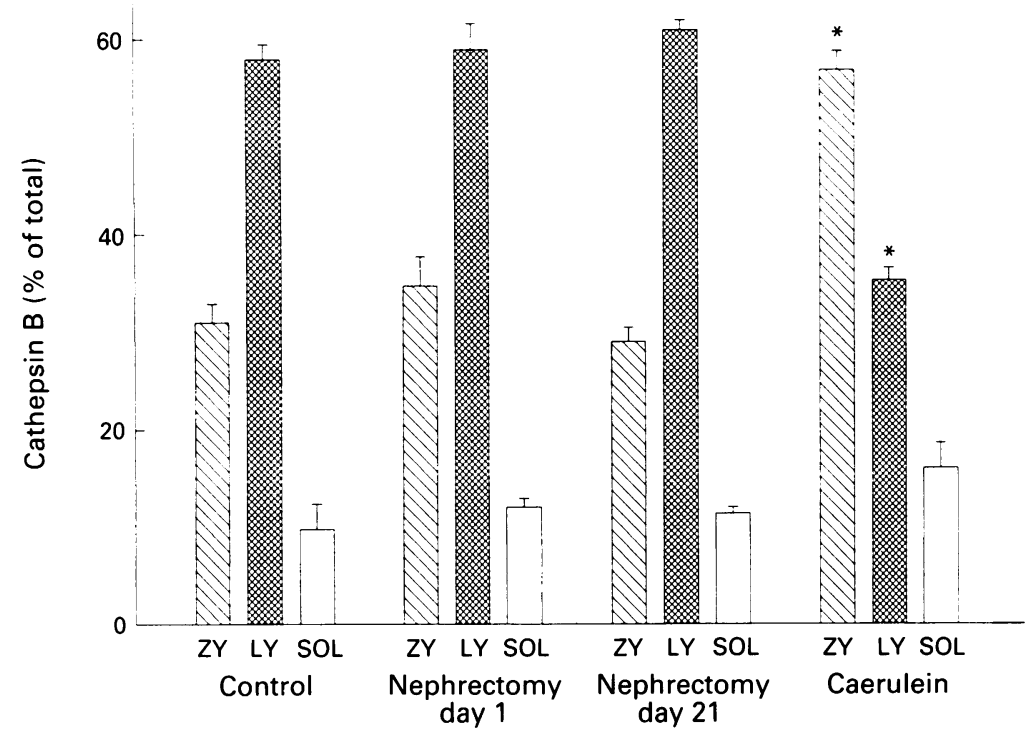

Figure 3: Distribution of lysosomal cathepsin B in subcellular fractions of the pancreas. After homogenisation of the pancreas subcellular fractions were generated as described in the text. The first set of bars represents the distribution of cathepsin $B$ in sham operated controls at day 1 . The fourth set of bars reflects the redistribution of cathepsin $B$ from its original lysosome enriched into the zymogen granule enriched subcellular fraction after stimulation with a supraphysiological dose of secretagogue (caerulein $5 \mu \mathrm{g} / \mathrm{kg} / \mathrm{h}$ over four hours). The second and third set of bars reflects the subcellular distribution of cathepsin $B$ at different intervals after subtotal nephrectomy and is almost identical with the situation in controls. Values represent cathepsin $B$ activities in per cent of total means (SEM) from four or more animals in each group. ${ }^{\star} p<0.05$ for the statistical comparison with the respective fraction of the control group.

different from control animals at the respective time interval.

\section{Results}

Subtotal nephrectomy induced a rapid increase in serum creatinine and blood urea nitrogen within 24 hours (Table), which gradually declined to values of $200 \%$ above normal by the end of the eighth week. No animal with renal failure developed pancreatic oedema and pancreatic water content remained within the normal range of between 71 and $73 \%$ water at all intervals investigated. In contrast, rats with caerulein induced pancreatitis reached a pancreatic water content of mean (SEM) 90 (2)\% after four hours of supramaximal stimulation. Serum amylase in the pancreatitis group increased dramatically and reached a maximum of 19753 (568) U/1 by the fourth hour. Animals after subtotal nephrectomy were found to have some hyperamylasaemia only after 24 hours postoperatively. Over the remaining study period the increase in serum amylase and lipase (not shown) was not significant (Table). Amylase and lipase activity in pancreatic tissue was unchanged during the first week of renal failure but was found significantly decreased after the third week (Table). A progressive increment was found in the measurements of pancreatic DNA, the number of acinar cells that had had necrosis, and the mitotic index of acinar cells. As expected, a higher number of necrotic acinar cells was found in animals with secretagogue induced pancreatitis. To discover if the changes in protein synthesis and DNA content were because of a fibrotic response of the pancreas we measured the tissue collagen content. Over the eight weeks of our study period no increase in tissue collagen could be shown (Table). The collagen content of the acute pancreatitis animals remained equally unaffected.

The hormone stimulated secretory response of pancreatic lobules during the early phase of acute uraemia was increased by 88 and $95 \%$ for amylase and for lipase respectively. In contrast, the stimulated enzyme secretion from lobules of caerulein pancreatitis animals was reduced to basal values (Fig 1). This complete blockage of secretion is believed to be caused by activation of
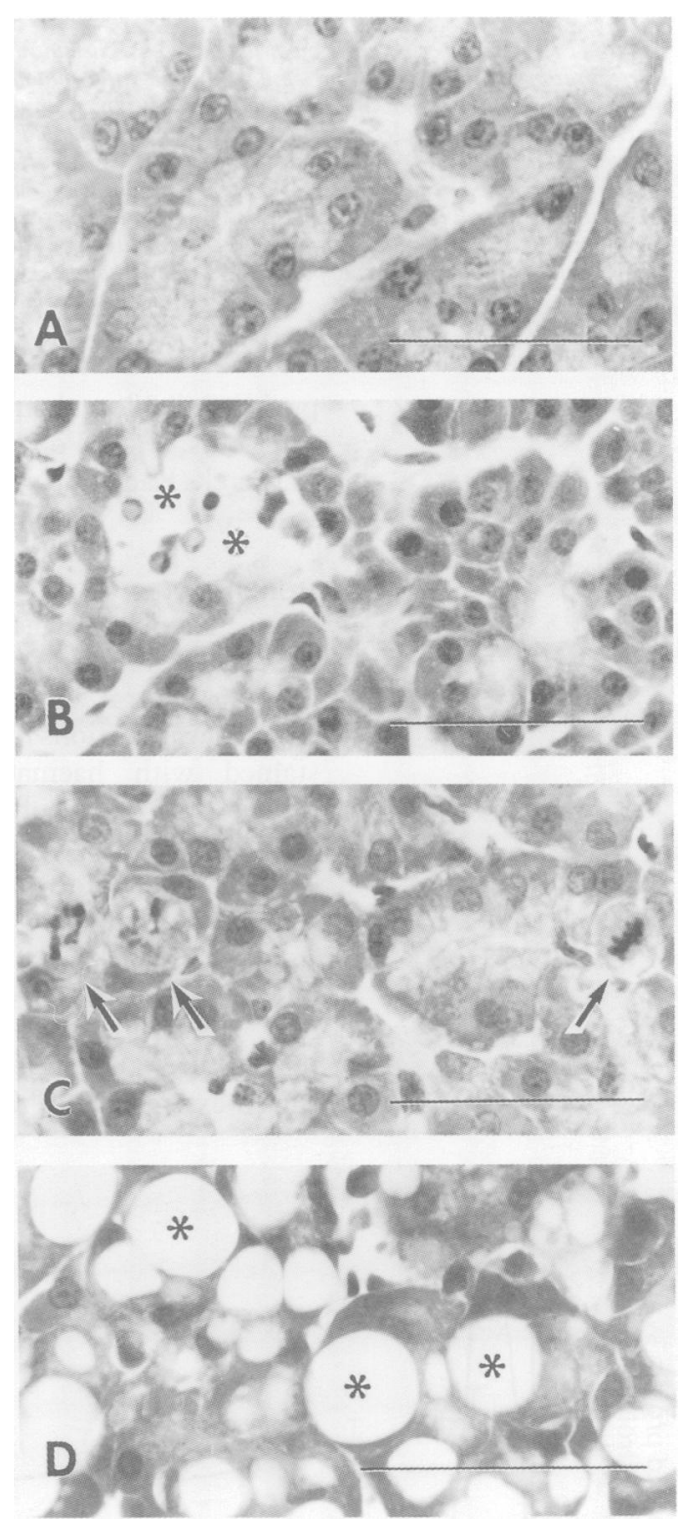

Figure 4: Morphological changes of the pancreas in experimental renal failure and pancreatitis. Animals were treated by subtotal nephrectomy or supramaximal secretagogue stimulation as described in the text and paraffin wax sections from fixed pancreatic tissue were stained with haematoxylin and eosin. Panels show representative findings from at least four animals in each treatment group. Calibration bars indicate $100 \mu \mathrm{m:}:(A)$ the normal acinar structure of a control pancreas. Sham celiotomy three days before death; $(B)$ unaffected acinar structure of the pancreas with occasional foci of acinar cell deletion $(\star)$. Subtotal nephrectomy seven days before death; $(C)$ as seen in $(B)$ the histological architecture has remained unaffected and without signs of oedema, inflammatory cell infiltration, autophagocytosis or fibrosis. The number of dividing cells is increased (arrows). Subtotal nephrectomy three weeks before death; $(D)$ to illustrate the morphological appearance of autophagocytosis (intracellular vacuoles are shown with ${ }^{\star}$ ) the section from an animal after four hours of supramaximal caerulein stimulation is shown. 
the low affinity state of the CCK receptor. After only three days of uraemia the secretory response of pancreatic lobules to maximal CCK stimulation decreased and reached a nadir at day five with $33(14) \%$ of the amylase activity secreted by lobules from sham operated control animals. Although exocrine function recovered slowly and in parallel with the recovery of renal function, values remained below control values until the end of our study period (Fig 2). The rate of protein synthesis, on the other hand, rapidly increased and remained increased throughout the eight weeks investigated (Fig 2). Protein synthesis in lobules from pancreatitis animals was not affected (not shown). The subcellular redistribution of lysosomal cathepsin B in controls and animals with caerulein pancreatitis was found to be as previously reported, ${ }^{13}$ in controls most of the cathepsin was distributed into the lysosom: enriched fraction whereas in caerulein induced pancreatitis it was shifted to
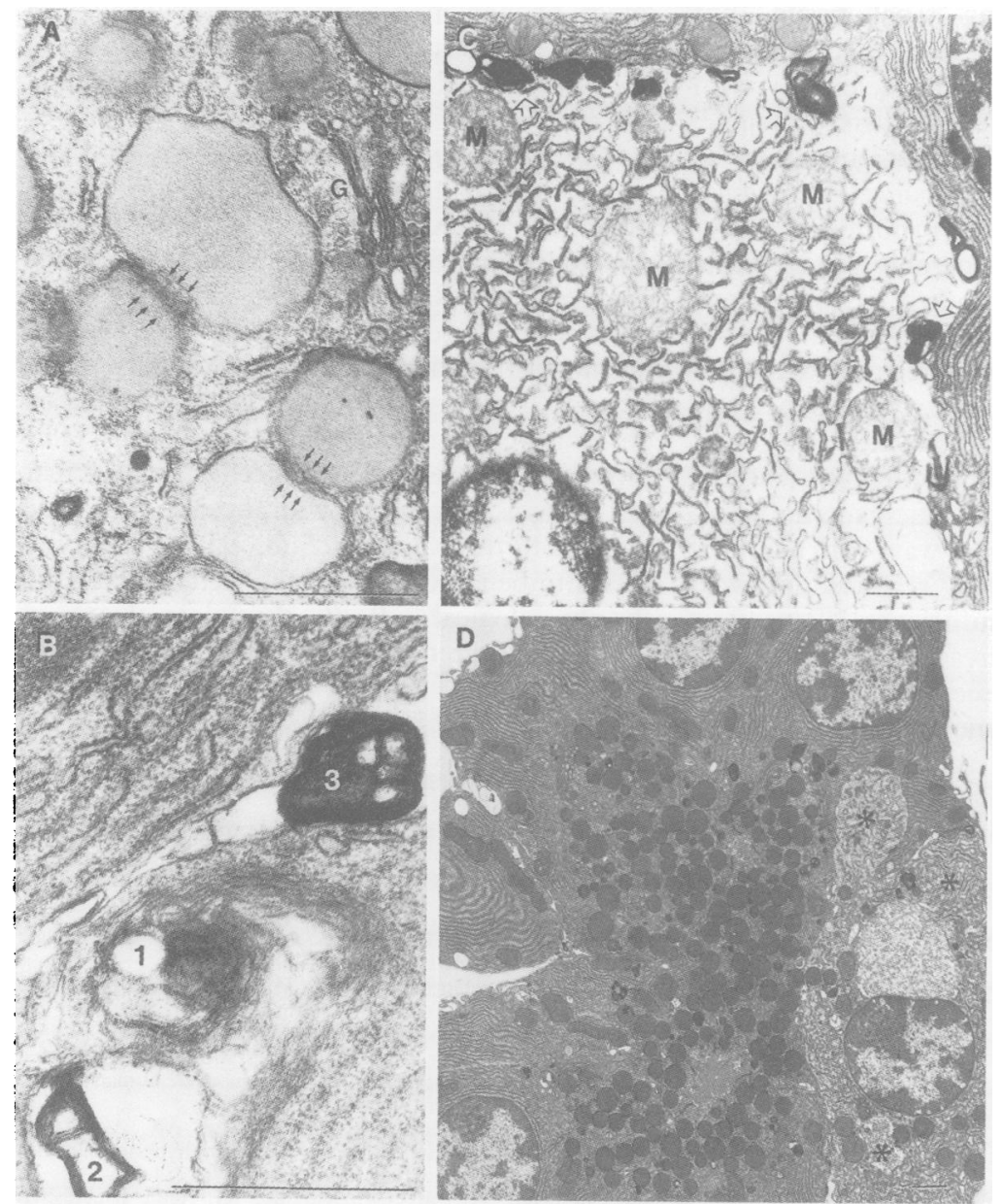

Figure 5: Ultrastructural changes of the pancreas in experimental renal failure. Animals had subtotal nephrectomy and pancreatic tissue was fixed at different postoperative intervals as described in the text. The photographs illustrate findings representative of those found in four or more animals at each interval. Calibration bars indicate $1 \mu m ;(A)$ immature condensing vacuoles in the post-Golgi $(G)$ compartment of the cell with apparent fusion of their limiting membranes (arrows). Subtotal nephrectomy 12 hours before death; $(B)$ flamentous material within the endoplasmic recticulum in different phases of condensation. The presumed sequence of aggregation that eventually results in the formation of a myelin body is arbitrarily shown with numbers from 1 to 3 . Subtotal nephrectomy one day before death; $(C)$ acinar cell during necrosis as shown by swollen mitochondria $(M)$, the surrounding fragmentation of the endoplasmic recticulum and the condensation of the nuclear chromatin to the nuclear envelope in the lower left cormer. Note multiple myelin bodies along the plasmalemma of the neighbouring, unaffected cells (open arrows). Subtotal nephrectomy three days before death; (D) low power micrograph of an entire acinus with a single necrotic cell on its right lateral aspect $\left({ }^{\star}\right)$. The remaining, unaffected cells are without ultrastructural abnormality. Subtotal nephrectomy four weeks before death. the zymogen granule containing subcellular fraction. This characteristic redistribution phenomenon was not induced by experimental renal failure at any time interval (Fig 3).

\section{MORPHOLOGY}

Sham operated controls were found to have no histological lesions in their exocrine pancreas (Fig 4A). From the first day after subtotal nephrectomy, individual or groups of acinar cells were being deleted from the pancreas (Fig 4B). These areas of acinar cell necrosis were restricted to small, scattered foci and the total cell mass affected by this condition never exceeded $6 \%$. In contrast with pancreatitis, no oedema and no inflammatory infiltration was found in response to this phenomenon. The number of dividing acinar cells increased in parallel (Fig 4C) and this increase was reflected in the raised mitotic index (Table). This regeneration was not associated with an increase in fibrotic tissue when sections were stained with fast green and sirius red (not shown).

Animals with secretagogue induced pancreatitis developed multiple autophagic and crinophagic vacuoles within the cytoplasm of their pancreatic acinar cells (Fig 4D). These vacuoles were absent in rats with experimental renal failure.

The first ultrastructural changes could be seen in the uraemic animals after 12 hours (Fig 5). While Golgi stacks were parallel and not dilated, the condensing vacuoles seemed irregular and fusion figures between individual vacuoles could be seen (Fig 5A). Multiple aggregations of filamentous material in different stages of condensation were found within the endoplasmic reticulum (Fig 5B). They corresponded with myelin bodies in size and shape and were absent in control animals. After the first day, cells having necrosis were found on the EM level. Their endoplasmic reticulum was dilated or partially disrupted into fragments. Mitochondria were grossly swollen and their dense granules and cristae had often completely dissolved (Fig 5C). The nuclear chromatin was found to be condensed to the nuclear membrane. The myelin bodies of cells affected in this manner were commonly found adjacent to the lateral aspect of adjacent, unaffected cells. When myelin bodies were counted, a maximum of 16 myelin bodies/acinar cell cross section (maximum of $63 \%$ of cells affected) was seen one week after the onset of uraemia. Necrotic single cells were regularly seen in uraemic animals from the first day until the end of the study period (Fig 5D). They were rapidly resorbed without any significant tissue infiltration by leucocytes and macrophages. The zymogen granules and apical plasmalemma with its microvilli seemed intact in unaffected acinar cells. Non-acinar cells, including ductal epithelial cells, vascular epithelium, and centroacinar cells were not found to be changed in renal failure.

\section{Discussion}

Uraemic pancreatic disease is a chronic disorder associated with exocrine pancreatic insuffici- 
ency, ${ }^{3}$ morphological changes of the pancreas, ${ }^{1}$ and a characteristic secretory pattern of digestive enzymes. ${ }^{21}$ According to necropsy studies its frequency has apparently increased since haemodialysis programmes were introduced for the care of patients with chronic renal failure and since the life expectancy of patients who participate in these programmes has dramatically improved. ${ }^{2}$ The pathogenesis of uraemic pancreatic disease is still unclear, but certain histological changes of the pancreas ${ }^{2}$ and the association of CRF with recurring attacks of abdominal pain and hyperamylasaemia ${ }^{22}$ have suggested that uraemic pancreatic disease can be regarded as a manifestation of pancreatitis. We have investigated the biochemical and morphological changes of the exocrine pancreas in an animal model of CRF. The initial phase of experimental renal failure is characterised by a rapid increase in serum creatinine and blood urea nitrogen and the animals develop transient signs of uraemia. ${ }^{9}$ Renal function slowly recovers over the course of eight weeks by means of hypertrophy of the remaining renal tissue, but complete restoration is prevented by the development of glomerular sclerosis with accumulation of extracellular matrix proteins. ${ }^{23}$ Two distinct phases of impairment could be identified when we studied acinar cell function in vitro. The secretory response to hormonal stimulation was increased considerably during acute uraemia, while after the fourth day a progressively diminished response was noted. This is in accordance with the pattern of secretory response to other types of toxic pancreatic damage, most notably that induced by alcohol. When dogs were fed a diet containing chronic additions of ethanol, pancreatic exocrine function was changed in a similar way, with an initial phase of increased secretory response followed by a phase of exocrine insufficiency. ${ }^{10}$ Pancreatic protein synthesis was increased in renal failure, but this increase does not seem to be a result of an increase in digestive enzyme zymogens. Both the enzymes secreted from acinar cells and the pancreatic content of digestive enzymes were decreased after the initial acute phase had passed. Therefore the most probable explanation for the increased rate of protein synthesis is cellular repair as shown by the increased mitotic index and the rise in pancreatic DNA. The impetus for this repair is shown by the number of necrotic cells found in CRF. Although the number of acinar cells that are consistently deleted is small in comparison with pancreatitis ${ }^{24}$ and their maximum number never exceeded $6 \%$ of the total cell mass, it is conceivable that these lesions induce hypertrophy and hyperplasia. Interestingly, this increased acinar cell turnover was not associated with pancreatic oedema, inflammatory cell infiltration or subcellular redistribution of lysosomal hydrolases. These three phenomena seem to be characteristic events in all experimental models of pancreatitis where they have been investigated. ${ }^{132425}$ Another mechanism that could explain the changes in protein synthesis and DNA content seen in our experiments and which is strongly associated with chronic pancreatitis is pancreatic fibrosis. Although it is probable that a fibrotic response contributes to the clinical pancreatic disease of renal failure we found no evidence for an increased collagen content or for pancreatic fibrosis during the eights weeks of our study.

The morphological appearance of experimental uraemic pancreatic disease bears little resemblance to the changes seen in pancreatitis. While immature condensing vacuoles and their occasional fusion has also been seen in pancreatitis," they are by no means characteristic. Dilatation of the endoplasmic recticulum, swelling of mitochondria, and condensation of nuclear chromatin are unspecific responses of the acinar cell that can be caused by a variety of events including toxic damage and impaired energy supply. ${ }^{26}$ While the characteristic autophagic and crinophagic vacuoles, which are found in pancreatitis 2728 were absent, uraemic pancreatic disease was associated with the occurrence of multiple intra and extracellular myelin bodies. These structures, however, thought to represent condensed phospholipid membranes, should not be regarded as a specific morphological phenomenon. They have previously been seen after exposure of the pancreas to a variety of toxic agents including ethanol ${ }^{29}$ and other nonspecific insults. ${ }^{30}$

We conclude that the biochemical and morphological characteristics of experimental uraemic pancreatic disease seem to be quite distinct from those of pancreatitis. Exocrine pancreatic insufficiency develops after an initial phase of increased secretory response to hormone stimulation. Increased protein synthesis and DNA content are paralleled by increased deletion and regeneration of acinar cells. The intracellular lesions that precede single acinar cell necrosis correspond with those seen in toxic damage to the pancreas. Subtotal nephrectomy seems to be a model that may yield insight into the physiological and pathophysiological interactions between renal and pancreatic function.

The authors wish to thank D K Nelson MSc for his critical review of the manuscript and A K Saluja PhD for continuing advice and stimulating discussion. Supported by a grant from the Deutsche stimulating discussion. Supported by a grant from the Deutsche Forschungsgemeinschaft \# Le $6251 / 1$
Freiburg University Medical School.

Presented in part at the annual meeting of the Deutsche Presented in part at the annual meeting of the Deutsche
Gesellschaft für Pathologie and published as an abstract in Verh Dtsch Ges Pathol 1987; 71: 96.

1 Baggenstoss AH. The pancreas in uremia: a histopathologic study. Am 7 Pathol 1948; 24: 1003-11.

2 Vaziri ND, Dure-Smith B, Miller R, Mirahmadi $M$. Pancreatic pathology in chronic dialysis patients - an autopsy study of 78 cases. Nephron 1987; 46: 347-9.

3 Owyang C, Miller LJ, DiMagno EP, Mitchell JC III, Go VLW. Pancreatic exocrine function in severe human chronic renal failure. Gut 1982; 23: 357-61.

4 Barcenas CG, Gonzales-Molina M, Hull AR. Association between acute pancreatitis and malignant hypertension with renal failure. Arch Intern Med 1978; 138: 1254-6.

5 Van Dyke JA, Rutsky EA, Stanley RJ. Acute pancreatitis associated with end-stage renal disease. Radiology 1986; 160: 403-5.

6 Lerch MM, Riehl J, Mann H, Nolte I, Sieberth HG, Matern S. Sonographic changes of the pancreas in chronic renal failure. Gastrointest Radiol 1989; 14: 311-4.

7 Putzke HP, Jonas L, Bienengraeber A. Vascular chronic fibrosing pancreatitis of the rat after $5 / 6$ nephrectomy. Exp Pathol 1977; 14: 113-21.

8 Kaysen GA, Majumdar AP, Dubick MA, Vesenka GD, Mar $\mathrm{G}$, Geokas MC. Biochemical changes in the pancreas of rats with chronic renal failure. Am f Physiol 1985; 249: F518-23.

9 Morrison AB. Experimentally induced chronic renal insufficiency in the rat. Lab Invest 1962; 11: 321-32.

$10 \mathrm{Sarles} \mathrm{H}$. Effects of chronic intragastric ethanol administration on canine exocrine pancreatic secretion. Scand $\mathcal{F}$ Gastroenterol 1973; 8: 85-96.

11 Adler G, Rohr G, Kern HF. Alteration of membrane fusion as a cause of acute pancreatitis in the rat. Dig Dis Sci 1982; 27: 993-1002. 
12 Lerch MM, Hoppe-Seyler $P$, Matern S. In vitro perfusion and incubation of rat pancreatic lobules in a kinetic model. Biomed Biochim Acta 1991; 50: 1115-25.

13 Saluja A, Hashimoto S, Saluja M, Powers RE, Meldolesi J, Steer ML. Subcellular redistribution of lysosomal enzymes during caerulein-induced pancreatitis. Am $\mathcal{F}$ Physiol 1987; 253: G508-16.

14 McDonald JK, Ellis S. On the substrate specificity of cathepsin B1 and B2 including a new fluorogenic substrate cathepsin B1 and B2 including a new fluorogenic substrate

15 Pierre KJ, Tung KK, Nadj H. A new enzymatic kinetic method for determination of amylase. Clin Chem 1976; 22: 1219.

16 Borgström B, Hildebrand H. Lipase and colipase activities of human small intestinal content after a liquid test meal. Scand f Gastroenterol 1975; 10: 585-91.

17 Labarca C, Paigen K. A simple, rapid and sensitive DNA assay procedure. Anal Biochem 1980; 102: 344-52.

18 Lowry OH, Rosebrough NJ, Farr AL, Randall RJ. Protein measurement with the Folin phenol reagent. 7 Biol Chem 1951; 193: 265-75.

19 Lopez-de Leon A, Roikind M. A simple micromethod for collagen and total protein determination in formalin-fixed
paraffin-embedded sections. $\mathcal{F}$ Histochem Cytochem $1985 ; 33$ : paraffin-

$20 \mathrm{Zat}$ JH. Multiple comparison. In: Biostatistical analysis. Englewood Cliffs, NJ: Prentice Hall, 1984: 185-205.

21 Otte M, Stahlheber H, Forell MM, Dobblestein H, Richert J, Thurmayr R, et al. Pancreatic secretion of patients with chronic renal insufficiency. Klin Wochenschr 1975; 53: 6772.

22 Araki T, Ueda M, Taketa K, Kosaka K. Pancreatic type hyperamylasemia in end-stage renal disease. Dig $\mathrm{Dis} S \mathrm{Si}$ 1989; 34: 1425-7.

23 Floege J, Alpers CF, Burns MW, Pritzl P, Gordon K, Couser WG, et al. Glomerular cells, extracellular matrix accumulation, and the development of glomerulosclerosis in the remnant kidney model. Lab Invest 1992; 66: 485-97.

24 Lerch MM, Saluja AK, Dawra R, Ramarao P, Saluja M, Steer ML. Acute necrotizing pancreatitis in the opossum: earliest morphologic changes involve acinar cells. Gastroenterology 1992; 103: 205-13.

25 Saluja M, Saluja A, Lerch MM, Steer ML. A plasma protease which is expressed during supramaximal stimulation causes in vitro subcellular redistribution of lysosomal enzymes in rat exocrine pancreas. $\mathcal{F}$ Clin Invest 1991; 87: 1280-5.

26 Plomp PJAM, Wolvetang EJ, Groen AK, Meijer AJ, Gordon $\mathrm{PB}$, Seglen PO. Energy dependance of autophagic protein degradation in isolated rat hepatocytes. Eur F Biochem 1987; 164: 197-203.

27 Adler G, Gerhards J, Schick J, Rohr G, Kern HF. Effects of in vivo cholinergic stimulation of rat exocrine pancreas. $A m \mathcal{F}$ Physiol 1983; 244: G623-9.

28 Watanabe O, Baccino FM, Steer ML, Meldolesi J. Supramaximal caerulein stimulation and ultrastructure of rat pancreatic acinar cells: early morphologic changes during pancreatic acinar cells: early morphologic changes during
development of experimental pancreatitis. Am $\mathcal{F}$ Physiol

29 Darle N, Ekholm R, Edlund Y. Ultrastructure of the rat exocrine pancreas after long term intake of ethanol. Gastroenterology 1970; 58: 62-72.

30 Herman L, Fitzgerald PJ. The degenerative changes in pancreatic acinar cells caused by D-L-ethionine. F Cell Biol
$1962 ; 12$ : 277-96. 